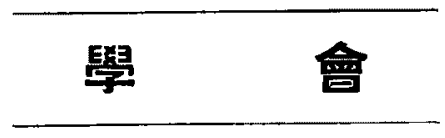

\title{
第23回中國四國眼科集談會講演抄錄
}

（昭和 11 年.11月 22 日 於倉敷中央病院）

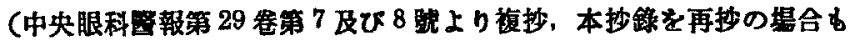
中央眼科篦より複抄の旨明記され度し.)

1. 二硫化炭素中毒によると考へらる る慢性球外視神經炎の㜔林的観察

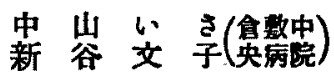

其の6 则を覞察せるが，自學的には雨眼中心很 力の低下を來すむ高度ならず，中心晤點は必缕な

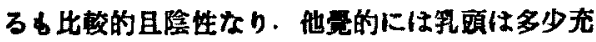

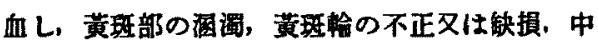
心窝反射の不正又は缺如等を見る。其の他全身 睷反射の亢進，血色素減少，エオジン㖺好栍白血

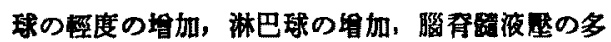

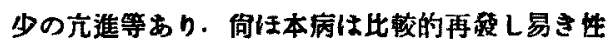
๘り.

本定の特長は腰椎穿刺によつて比較的速に良好 の絓過を取るに㧦らち、球結膜下に高張性食煘水

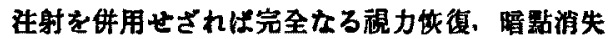
を見ざる點なり。

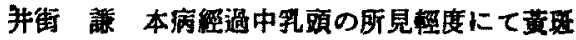

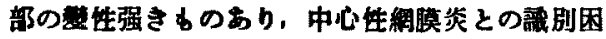

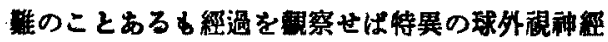

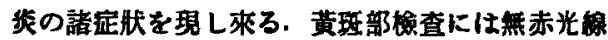
を阱用すべきなり。

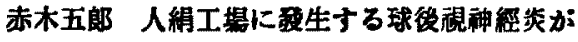

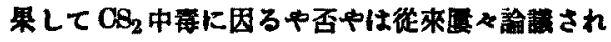
た所なり．演者は如何なる點を目僄として之を $\mathrm{CS}_{2}$ 中毒によるとされしゃ，向は此隐に於ける身 狚的及び精神的定状は如何.
2. 急性球後視神經炎の 1 例

$$
\text { 佐タ木トラェ(威山病院) }
$$

33葴の女の左眼の急性球後神經桨の 1 例に就て

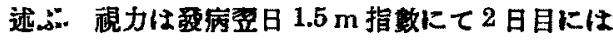
光學すなく9日目より少しづつ視力堵進せり．原

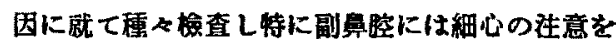
排ひたるる所見なし、只氏反㕍(十)なりしをらて 掘徽撚法を行ひたり。

3. 患側に網膜中心血管血㻺の異常低 下を見たる 1 側性腦横窟炎の 1 例 に就て

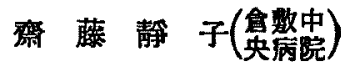

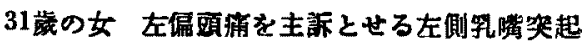

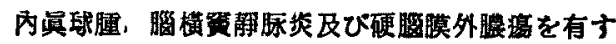
ろ患者に就て影回に互り網膜中心血管血慰を測定

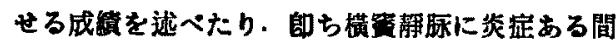

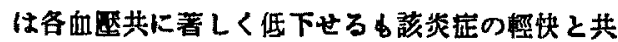
に正常に復し在右の差隇少す。

4. グレノー氏角膜泟濁の組織的所見 鹤見義夫(岡大)

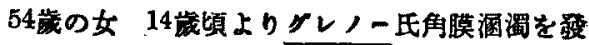
し、 7 年冽及び 3 年的の 2 回某病院の手街を受く.

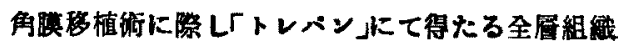

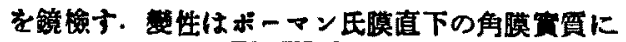




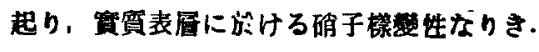

曲直部正夫㧒役部位及び受生機轉に就ては與 昧ある問題なるが此點演者の考按如何.

倠見戔夫 今後の研究に俟つべきすのと思かが 寅者の鏡檢所見よりちれば先づホーーン氏膜直下 の表居筫筫に何等かの機嫥によつて筫性を生ぜろ ஆのと思ふ.

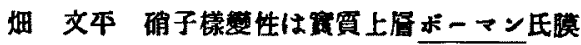
直下の嘚に一面にあり.手術的缲作の加はりしむ の故原硫性の病爱とは差異ららん.

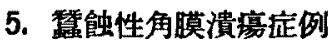

$$
\text { 田丸 朔 (四大) }
$$

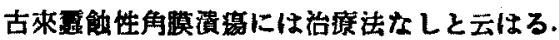
演者は其の惑を深くせる2例を報告す，第 1 例は

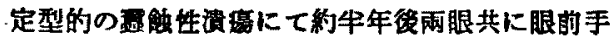
動の睍力となり，第 2 则はトラコーーバンヌス」

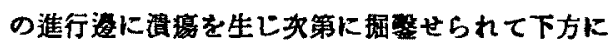
進み手動を辦ずるのみとなれる一異型なり．

6. 蜂敬性角谟炎の 1 例

船石平八 郎 (京大)

24 藏の男子 右眼角膜中央部に「スズメバチ」 による蟞鹤を受けたり，約 2 週間後に訩たる所見 は著明なる周擢冭血あり角膜は一面に表在性及び

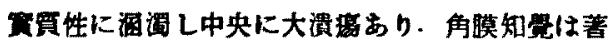

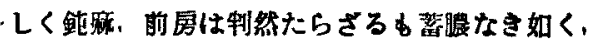

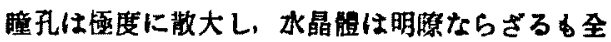
䯏白く洞调せろ如 L. 視力は眼的手動。眼压は $50 \mathrm{~mm}$.

山本向武 脚長蜂を用ひ家鬼角膜を刺さしさる

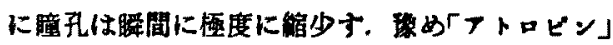
點眼，「コカイン」點眼，「ゥレタン」筑䡋を行ひし

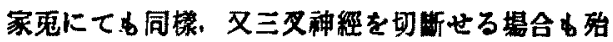
どそに新し.
7、生殖腺製劑の眼局所應用が静脉內 に注入せる「フルオレスッエン」の 前房移行狀態に及ばす影暨に就て 丸尾孝 正(拿病中

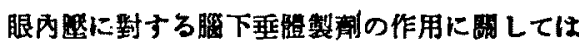
多數の研究あるむ，之と泌接の開係にある生殖腺 の眼㕍作用に閶しては比较的少く且男女の性ホル モンが夫ふ同性及び異性に如何なる影暂を與へる

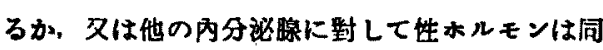

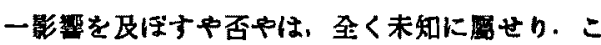
の間係を研究せんと䣄し第1 報として「フロレス チンンーダ」の前房內栘行が性ホルモン家鬼眼結 膜下注射によりて如何なる影整を受くろかを榆せ しに 1)男性ホルモンは男女兩性に對して「フロ レスチン」液の前房内移行を促進せしむる作用あ ろ6. 2) 女性ホルモンは女性に對してのみ該促 進作用を星せり.

8. 岡山鲧第一岡山中學校第一悬年 生徒眼檢診成績に就て

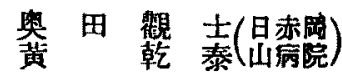

第一周山中學校一脾年生徒 259 名に就て一般眼

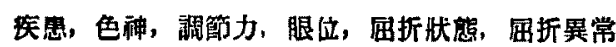

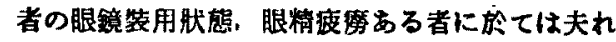

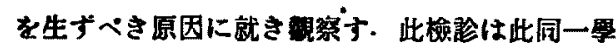

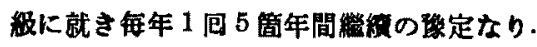

松尾挛陫（1）被榆者 259 名中「トラコーマ患 者 7 名走除き，殘り，252名中，結膜裉脆を有才 ろ者 233 名の多きに道せる點は我くの踏想外に多 きに謷きたるなり．（2）眼鏡装用者 59 名中, 眼科 因の處方によるむの16名に過ぎず，殘り，43名 射ち大多政は眼鏡店の检眼による.一中生徒は殆

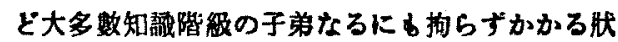

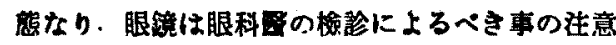
を一般人士に知らしもる必要かり。 
船石平八郎 京都市丙虛昭小學兒童約 85 名に 就て，主として結膜に重點を置きて椛診せるに約 97\%に於て結膜㵍胞の存在を認めたり．即ち演者 の舉げたる統計値に近似せるを知る．但し余の埸

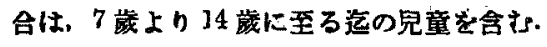
-

9. 頻面紅色母斑に合併せる綠內障

$$
\text { 小山綾 夫(岡大) }
$$

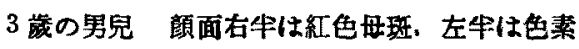

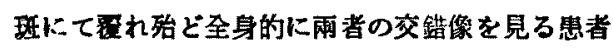

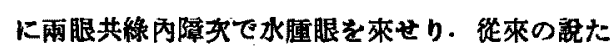
ろ綠內障の多血性原因乃至シュレム氏管の異常は 本例に於ては根㹉畹し，依りて演者はレートの如 く植物种經系の異常に估るすのとせり．

10. 全腿球炎の应狀を呈したる水晶體 前房內脫臼に依る綠內障の 1 例 小山綾 夫(岡大) 55 嵗の男 左眼に 10 年來白內障ありしを放置 せるに或朝哭如眼痛，毛䓠充血，前房水白濁等を 來し其の状全眼球焱の如き思者に就き的居洗沙を 行ひたるに其の䟢「ヒョレステリン」結晶㥞のす のを認めたり．患者の苦痛は即座に去り良好なる

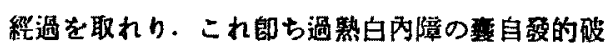
裂に依る綠內障なり。

11. 慢性婳草酒精弱視の 1 例

$$
\text { 東貞 雄 (岡大) }
$$

41 蔵の男熛草は「バシト」1日4凰以上，酒は 洋酒を好まず主として日本酒 1 日 1 升乃至 2 开， 時に煙草を哥として1升位の酒を饮む。約 1 年的 より笰視，書盲应を訴一來りし者，眼底所見とし

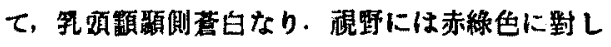
て注視默よりマリオット察點に互る横畉形の陰性 比僌的暗點を證明子。定型的の慢性㖶草酒精弱覞
にして，禁酒，沃制內服，高张食祭水結膜下注射 を行ひ約 2 简月にして全治せしめたり。

12. 稀有なる角膜火傷例

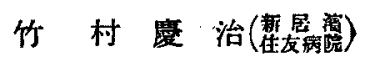

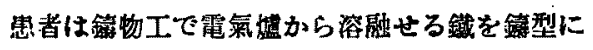
注入する際，譟つて兩眼角瞙火䈓を起せるもの， 兩眼角膜全面が白色を呈す. 治療約 2 週間で右眼 は愳力 0.7 以迄饭復したか， 左眼は逐に角膜全届

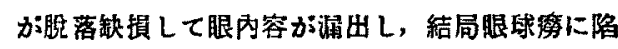
つた.我《の工場では良く角膜火稘例に瞥遇する が米だ 1 侧る失明したるのはない即ち本例の如 く失明せるすのは極めて希有の火甥例である。

筫越 中 余の勤務する造船部病院に於ては日 日，角膜火侮侧を訅するが，演皆の如き重篤なる ののに未だ接せず. 熟れす「ハッע山に依る小火

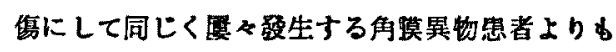
其の稳後は佳良にして，多くは痕跡を㙛さすして 1, 2 日にて治雭子。

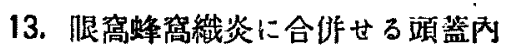
合作症

$$
\text { 日淺静逸(凮大) }
$$

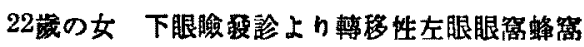

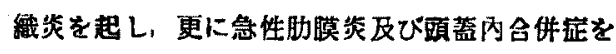

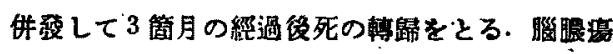
ならん，演者は本定刚に於て超短波療法及び持繶 的腦春略液排出法を試みたる旨を述へ；更に眼性 頭蓝內合併症に對し眼科監は徒らに敬遠与る事な

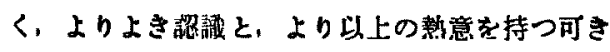
ののなる事を述ぶ.

百々次夫 11 賞の男子 約 1 遇間前上り惩感戰

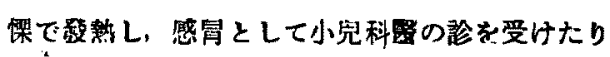

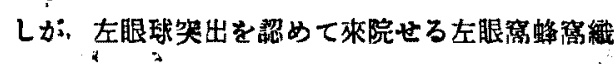

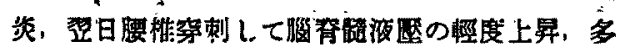




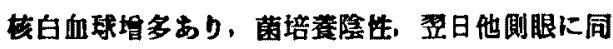

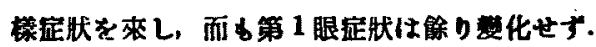
全身定肰篮太惡化し，其の翌《日死亡十，不幸

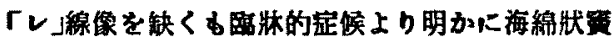
の栓塞性解腺奖の存在を思はしを.

14. 再ひ「バルキンソニスムス」に就て

安井正俊 (岡大) 「ベルキンンニスムス」の2 甽に就て追加毀告せ

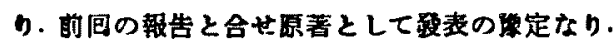
高木 齐 演者の第 2 例の眼球上方衰引の刚に

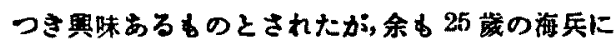

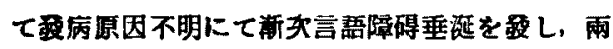

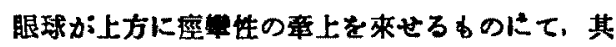

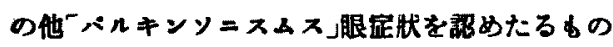

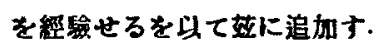

15. 所謂眼筋無力㱏に對する「プロスチ

$$
\begin{aligned}
& \text { グえン」(ロ产シュ)の效果に就て } \\
& \text { 布 村 晴 雄(京大) }
\end{aligned}
$$

17 荿の男子 15 瓷の春に眼睑下垂と複視を來 たした．－時㱠ど台㞼せしが本年 1 月上り再要

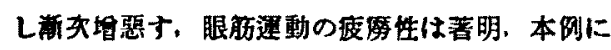
Prostigmin を皮下注射し10 分每に眼運動状態の

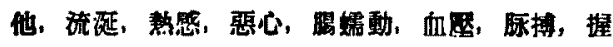
力等を梌せり.Atropin $1 \mathrm{cc}$ 注射很 10 分上り效果

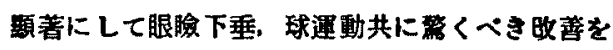
示する， 2 時間にして元の肰態となる. $2 \propto$ 注射 後は眼速動は放ど正常となりたるも效果は約 3 時

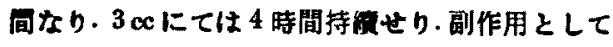

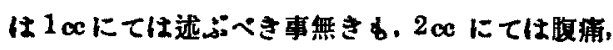

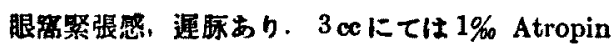

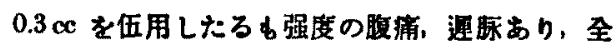

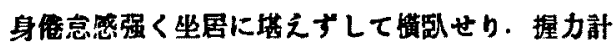
にて测定したる值は不警なり，爾後隔日に $2 \propto を$
1\% Atropin $0.3 \propto$ と共に用ひ，常に著效を見た ろも一時的なり即ち本成综は Walker, Laurent 字の行ひたる肪無力定の定例に於けると同嵄な b.

井街 謙 49 歲の男突然 考眼上眼睑下垂定に 始口左眼眼球の左，右，下方運動障碍を來し，渐

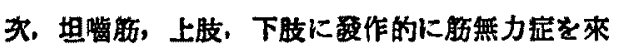
せるるのに「プロスチダミン」を用ひ一時的轻快を 見たろ附を遑加す。

\section{6. 邦人正元見眼者調節線に就ての一貫}

驗（調節時の焦點深度）

$$
\text { 加來 球 暨氞) }
$$

任意の方向に視票(毛)を貼布し得る 2 畨の梅を

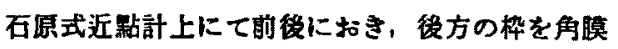
首 $20 \mathrm{~cm}$ に固定し、前方の梅を移動して前焦點深 度を求めた。深度は 3 乃至 $6 \mathrm{~cm}$ て之より Rohr 氏の式によつて䠝輸の太さを求めて 0.0064 乃至

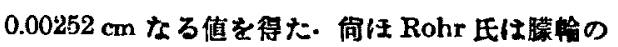
直徑は $0.00489 \mathrm{~cm}$ なりと云ふも氏の得たる表中 の教値による時は $0.00504 \mathrm{~cm}-0.00491 \mathrm{~cm}$ なる 結果を得る. 視徱の方向は，前後杵のるのが大略

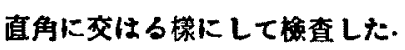

\section{7. 所謂狹義先天性停止性夜盲に就}

$$
\text { 內 山 宗一(拿喜厚院) }
$$

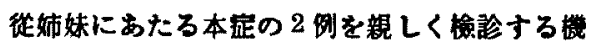
會を得，其の家系を調查し尚は 2 名の本定に該當

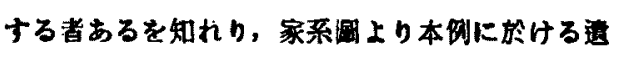
保型式は川上氏分類によろ本正の 3 種の寈傅型式

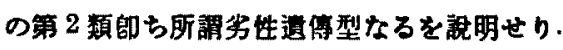

18. 翼狀版に伴へる結膜算腫に就て

$$
\text { 片山雄 (三原) }
$$

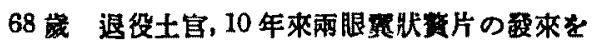




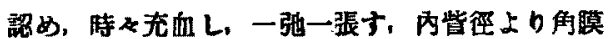

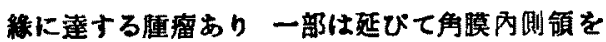
蓋ひ属は底面に固着し移動せず彈力性硬度を有し

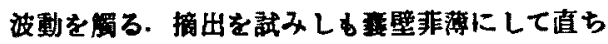

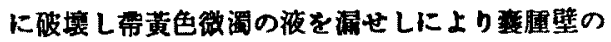
一部を切除し内面を强破嬈灼術を終る．其の後經

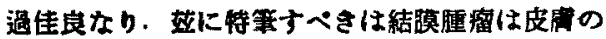

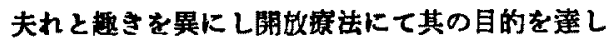
得るにより困踓なる全組䍃の摘出を姴せざる事な b.

19. 血乳頭の 1 例特に視神經內求心 性淋巴道障碍に就 曲 㨁 部 正夫 (京大)

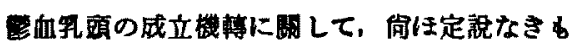

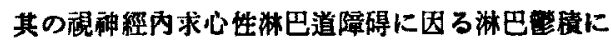

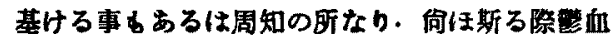

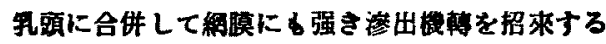

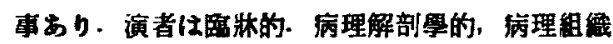

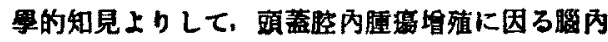
厘上昇に原因し視神䄳內求心性淋巴液路に变㥂を

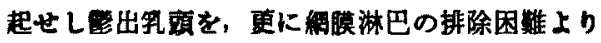

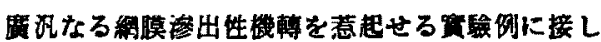
得たれば，標本供罯这に報告せり．

\section{0、一側惱牛球萎縮を伴へる視神經萎} 縮の 1 症例

$$
\text { 百 次夫(京大) }
$$

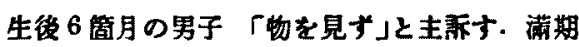
安詹なりしが，生後 4 日目に短期持維性指场性全

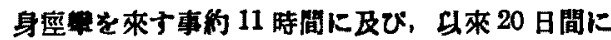

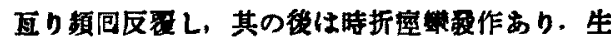
後 3 箅月時に上記主标の下に外來を訪んしが，高 度近視の外著隻無きため放置せられ，更に 3 簓月

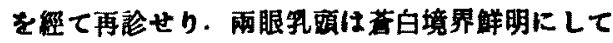

網膜動趼狄少 乙單性萎縮の像的り，頭部は签度長

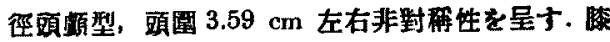

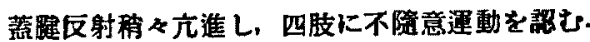

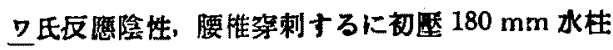

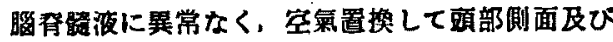

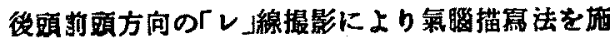
行す，印ち高度なる左側腦牛球萎縮立に各臘空に 互る內腦水腪の所見を得たり.惟らに生後 4 日に

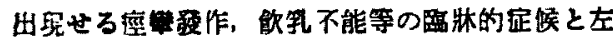

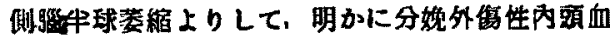
腫乃至腦出血ありて之等全身应状を惹起せしが．

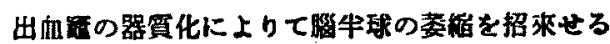

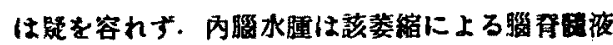

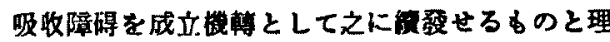

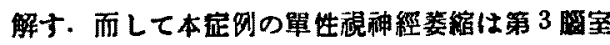

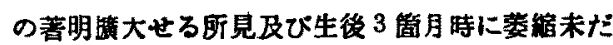

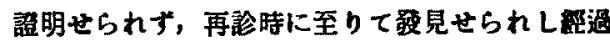

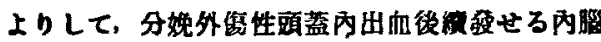
水䭪の視祒經交及部臀迫に基因せるものと解与。

21. 卵白によるフレルギー性疾患 石田憲吾(明大) 第 1 刚 2 年 9 月 女子 身體踓常、生後 1 年

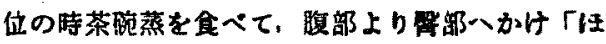

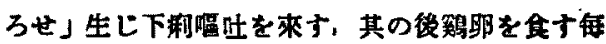

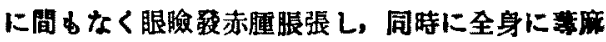
参を生じ，多くは一夜にして诒雭す．生後牛年の

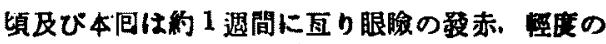

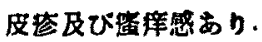

第 2 例 75 日 女子 生後卵白で䇺を洗ひ䄪 1

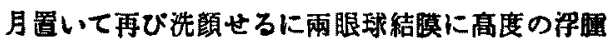
生し，睑裂外一迄出る，充血はなく 3 日掼消失 †.

第 3 则 4 月 女子 生後卵白で政回洗䫀的 2

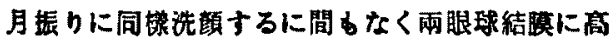




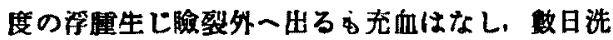
眼して治虑与。

22. 學路期膿漏眼患者の性别統計

$$
\text { 北島守墼 (高禁) }
$$

昐和 2-11 年の10年間に本院に收容治愿せる浱 樰眼患者 145 名を性及び年齢につき分つに成人に

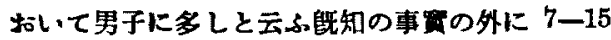

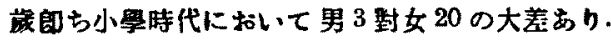
且其の大部分が淋菌生陰門笑を有すること(陽性 10，隍性 2，不榆8）反び男兒には1. 例の淋疾なき

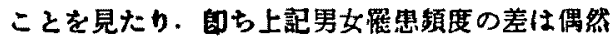
にあらずと信ず。

23. 自案簡易眼電法器に就て

$$
\text { 高量正夫(周大) }
$$

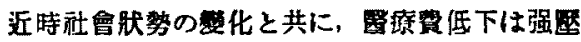
的に行はるるに至る。醫業經營は合理化を们進さ れる. 其の一蝡として標記のりのを作り 1 年間使 用したが合がよい，從來䅖くの眼器法器ある。 一長一短あり、蒸氮罳法器は防水布等厄介で手數

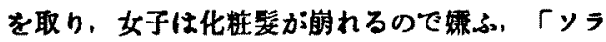
ックス燈」は夏期額や䜿が火照るので䗲はれ，又 比䡆的高傎である. 手持式のいのは患者が次くに 替ると一《消毒してい憡がるのがある，余の供 筧するるのは以上の點を幾分政良せり．構造は電

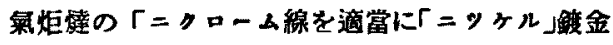
せる金盗にて蔽ひ，眼を賞てる部には石棉を用ひ 「スタント」を附して上下自由にせり，姴するに卓 上用「ッラックス復」を小型にして電球の替りに 「ニクローム線を用ひた樣ないので圆䧄 8 圆，電 力50「ワット」で鳘磁的である.

24. 松尾式簡易洗腿器供㹂

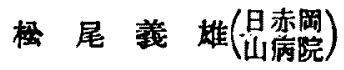
余の考案にかかる简易洗眼器を供睍し、其の使
用法，用途等に就て演述せり．

25. 角膜移植例（患者供㹂）

$$
\text { 畑文平(岡大) }
$$

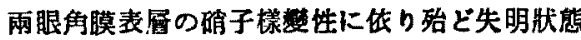
におつた患者の 1 眼に, 網膜瞕腫に低て眼球摘出 の涂儀無かつた患者の角膜を直彺 $3 \mathrm{~mm}$ の「トレ ペン」にて劭除し，移植せるに術後克く源合し40 餘日の今日迄全く透明を保方居る1例を經䮲せる 故患者を供睍して一般の考に供する．54 嵅，女

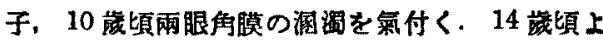
り視力陪碍㙕し 7 年前及び 4 年前の 2 回に互つて 某大學病院にて手術(叠爬)を受け一時視力堽進せ

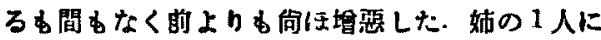
あ同茲の疾患がある.

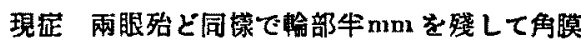

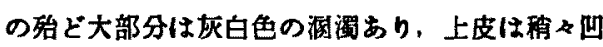

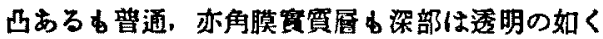

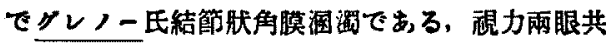

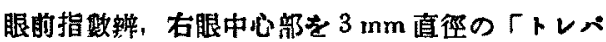
ン」にて全層町除し这に次の慗者より取りし角膜 片を慨入し歴迫縌帶を置き 3 日目に检せるに少し

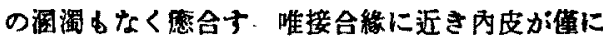
灌く溷濁せるのみ，中央部大部分は全く透明であ ろ. 10 月 10 日手術し，10月 22 日視力 $15 \mathrm{~m}$ 指

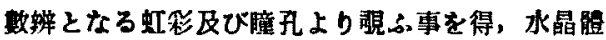
に末彮白內障を破見ナ，以後今日迄 10 狳日を經る あ移植片の透明度殆と謷化無く視力は $2.5 \mathrm{~m} \mathrm{FZ}$ $(4 \mathrm{~m} \mathrm{FZ} \mathrm{m}+0.5 \mathrm{D}+\mathrm{Cyl} 0.5 \mathrm{D} \uparrow)$. 猶任角膜片 を供給せる患者は 4 蔵の男，昭和 10 年 2 月より網

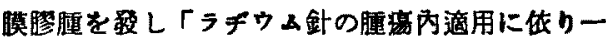
時轱快せるす本年夏 8 月頃より再び增殖 し全く摘 出の止さ無きに至れるあのにて，前記㭧者と同日 に再診に來り角瞙片を供給せるは奇緣と云ふ可く 失明眼め亦再生し得たりと云ひ得やら。 
26. 白內障手術後の結核性虹柇毛樣體炎

河 原 省 平(骨山市病院)

45歲の一見甚だ㜔康なるかの如き患者に白內障 手術を行ひ，手術竝に術後の經過は全く圆滑なり

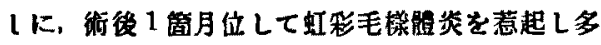

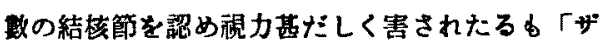
ルッーブロカノン」「ウムスチン」等の过射站に眼 局所治璄により炎定消退し幸にして失明よりまめ がれさり，一見甚だ健康なるも内科的垃に「レン

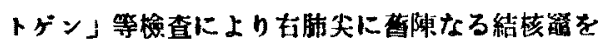
認めたる征例に就て述へたり。

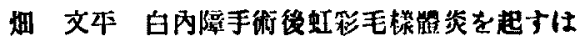
比䡈的多い事であり，之に定型的結核節を生ずる るのあり或は前房音眼性虹彩毛棱體炎を見或は結 核フレルギー反礁と見らるるすのありり、白內障

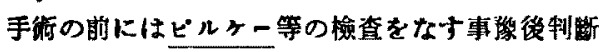
の上に效めらん。

井街 訸 京大眼科にて水晶醩蛋白に對する過

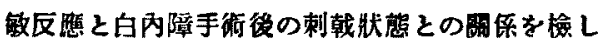
たる事ありて，兩者の平行性を見たり結核以外に

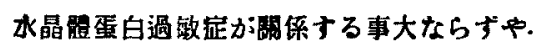

27. 砲彈片による眼外傷 1 例

$$
\text { 高木諳(吳海軍) }
$$

某海苯三等兵曹 23 歲 本年 8 月趿移中 $2 \mathrm{~m}$ 前

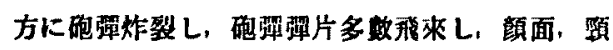

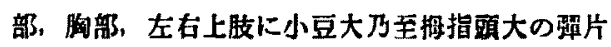

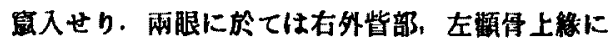
各 1 筒小豆大の彈片侵入創あり。外伤賞時は，雨 眼に高度の視力障碍ありて，直に某病院に入院せ り. 10 月 7 日即方外的後 1 简月牛䅔通後に於て，

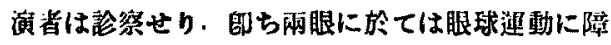
碍なく前眼部には何等翼常㤵し、眼底の逶视可良

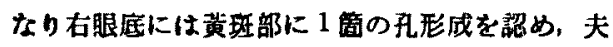

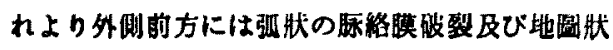

の萎縮乃至網膜出血及び色素の旉出あり．左眼底 に於ては䩜班部及び其の外前方に不規則なる網豚 络膜䤑裂の缘を認め，視野は右眼に於ては，中心 部及び買側に著明の視野缺損あり，左眼に於ては 中心部を含む悬側上部 4 分 1 部の全缺損あり. 視 力右 0.1 在 0.2 なり.「レ」線榆查を行ふに，右眼に 於ては眼窝內にて外壁の梁部に 1 筒。左眼に於て は眼窝內にて下壁の梁部に 1 筒小豆大の彈片寍入

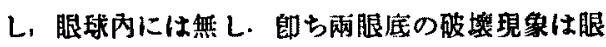
畕內に层入せる雒片か眼球を直接打菐せる結果に 上るものなり，而す眼膜を穿れせす斯の如く的鄂 嘪入により前眼部に大なる損鹪を興へず，眼底に 高度の股墱を來せる峜附は甚た稀有なり．

28. 桨小學校に爆發的流行名來したる 急性結膜炎

$$
\begin{aligned}
& \text { 筒开德 光(岡大) } \\
& \text { 赤木五郎(岡大) } \\
& \text { 山 崎 義 節 (篎街) }
\end{aligned}
$$

䐆下山間部某小校に於て校醫が「トンコー」 兒童 101 名を洗眼治滰中に該兒童の過半は僅々数 日中に剧しき急性「カタル生結膜笑に犯され，其 の多数は莩緣「フリクテン」をあ合併し開臉困難と

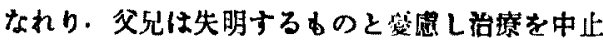

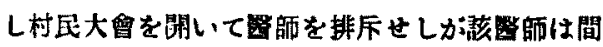
すなく老塞にて死亡せり．他に矮師無き地とて更

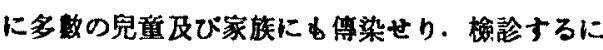
シシホウイークス氏菌結膜焱の定型像を呈し，棌

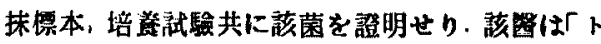
ラ」治璄に最初 1-1.5\% 銀水を使用せるに刺载强 かりしため「クペロン」に代へたるに数名の急性

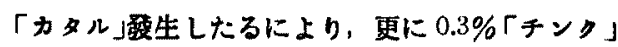
水絬眼のみとせるに爆婹的に流行せるすのにて，

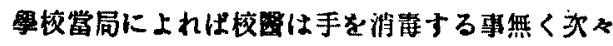
洗眼せりと云ふ.上等は本流行と梁き閶保あらん。 
友保正雄 岡山市內或工場に於工本年 7 月初旬

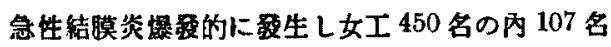

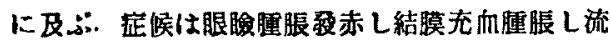

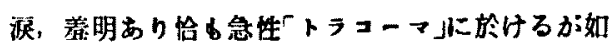

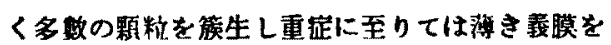

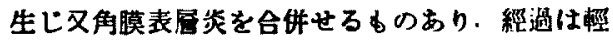

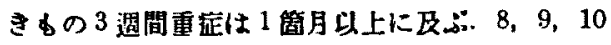
月に互りて流行し11月に入りて断く隇少与.初政 以來全工の約 $60 \%$ に及心：榆菌再三榆查せしか漧 嬠菌を榆出せり。

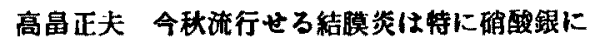
て疼痛を济ふる者多し、村㹂が确酸銀を用ひてい， たか，疼痛の雼中止したとの事なるが，この最合

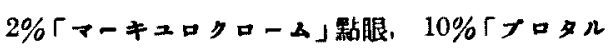
ゴール」點眼後洗眼するに疼痛なく成綃良き如し. 演者の沿㞠法如何.

筒井德光 コ一立氏菌結膜炎には硝酸银水を 用か. 其の他「メチレンブラウ」「マーキ2ロク口 一ム」等の色素看内有效にて之等使用与。

29.「スパーフ」に上万中心性網膜炎 筒 非: 德 光 (阙大) 20 藏の雪籍工 眼前 $20 \mathrm{~cm}$ の近距離にて猛䓡な 「ショートスパーク」の矓辉を受け，直後は眼かくく らみて何物す見之ナ゙，其の後は稀視あり，左眼は

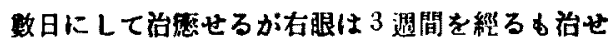
すとて來る，中心性網膜奖の所見を呈し，他に結

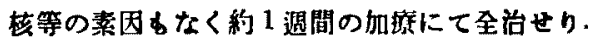

本病の原因諭種※むるが本例は光力學的作用に上 るっのなり.

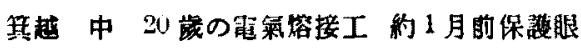
鏡を使用せす操業せるに其の後兩眼共ウロウロし て中心を凝視し得ナ，中心晤點，中心管の紅色者 色等むり，光線が原因と思惟され雨眼侵されしも

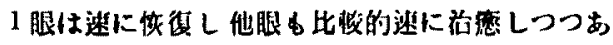

る點演者の例に類似ナ。

30. 日触性網膜炎に就

橋本真平(岡大)

昭和 11 年 6 月 19 日の日触得旺に原因せる網膜 炎にて岡大眼科に來れる5别に就て主として其の 視野及び革斑部の變狀を述ぶ。

第 1 例 32 藏の女 雨眼に来り小なる中心题點 あり，中心筥は幾分浮腫怔なり。

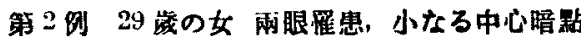

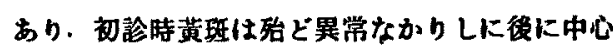
窝は赤色となれり。

第 3 侧 23 藏の女 左眼黃玨部に黑色色素あ

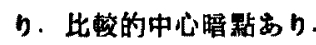

第4们 16 藏の男 左黃玟部紫黑色中心部に比 慗的大なる絕對晤點らり。

第 5 侧 38 濒 雨眼中心窝幾分照色を呈し中心 部に暗點むり。

31. 日蝕性網膜炎に就 $\tau$

吉朴良梅 (尾道)

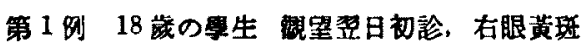

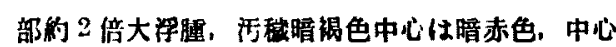
晤點古り。

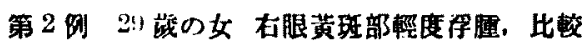
的中心晤點 (十) 視力 0.8

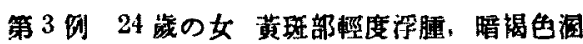
斶. 中心晤點 $(+)$ 視力 0.6

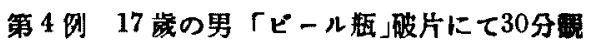

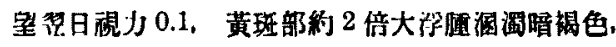
中心暗點( + )

32. 日猞性網蕰炎の 10 例に就て

$$
\text { 详 本 正 堆 (京大) }
$$

京大に於ける 10 时に就て見るに年龄は 22-49 战，女4男6，雨眼6 片眼 


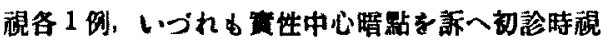
カは 0.2-1.5にて中 7 侧は税力正常に復せるも向

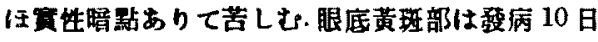

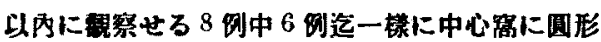

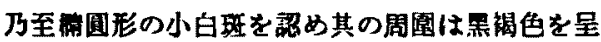
せク，中心䀧點は唯 1 刚約 4 度の大さを示せるす

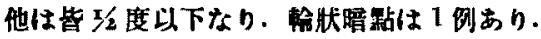

丸尾孝一 演者は無赤光線にて眼底を略祭せる や、余等の 2 例を之にて見るに黄玨部に正圆の班

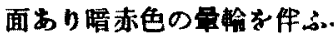

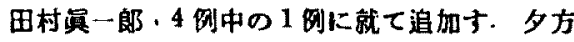

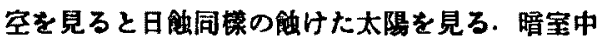
にて陽性遺像を見，日光を受けた檫确子に面して

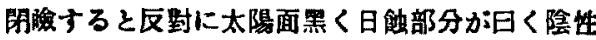
掘像を見る。

并街 潇 無赤光線に上る所見は初期は輕度に て3ー4 日に至り高度となり，中心部は黃色に周图 は膘黑色に見之るが款次中心は灰色に黑色徐は消 退す．此所見より先づ豚絡膜に浮腫を生し網膜等 㚘は之に狄で起るとの Birch-Hirsshbeld，秋山氏 等の境に梖成子。

岸本正雄 小白琣及び暗赤玨共に熋通光線より は無赤光線の方が著しく不明眿なり．其の他の眼 底所見は無赤光線にてす㫪通光線にてす大なる相 違なし.

33. 再び奇異なる眼底像を呈する所謂 中島氏症型に就

$$
\text { 箕 越 中(网大) }
$$

前回奇異なる網膜血管吻合を有する中島氏提唱 の病型を報告せる際，一步を進め之を網膜蔽萄膜 血管の異常を主とし種くの策脽を附陾する一種の

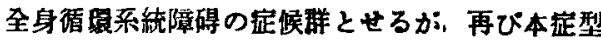

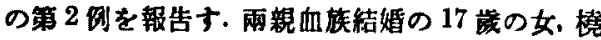

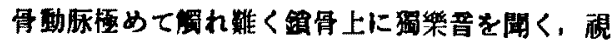

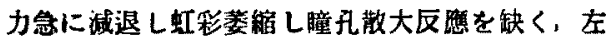
眼の昷化强 L.

內山宗一 前问寒越君と共に報告せる症刚の其 の後の所見は左在共に光觉，雨腿高度の網膜制雕 あり．左眼白內障を認む。

34. 無冀斑应の 1 例

$$
\text { 森滕三郎( 大野泟院) }
$$

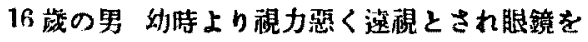

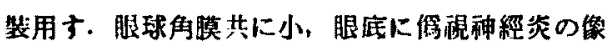
あり、黄理部動彩脉は稍々大きく通常黄玨のある べき位置を通過 L黃玟は全く㽞められず，父母は 從兄妹結婚, 遗視 +11 D. 原因は要育異常ならん.

35. 所謂眼迷走神經反射傳故路に於け る交感神經㵶維問題再吟味

$$
\text { 北街撞(倉警中) }
$$

日眼繶曾席上交感神經が所謂眼迷走神經反射に 必要不可缺の徑路に非ざる旨を述べたるが，其の

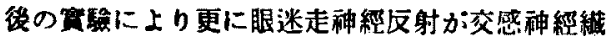
維と全く無闒俰に起り得るいのなることを斷言せ んそナ.

36. 再び余の簡易なる白內障全摘出術 に就て

$$
\text { 畑文平(岡大) }
$$

昭和 7 年释表せるるのに更に政良を加へたり．

（1）㸝角膜切開。千ン氏票切断鈎㨉入に上る上

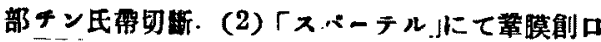

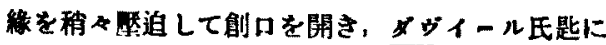

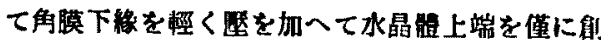
間に哯かしむ.（3)「スパーラル」を捨て曲匙を創

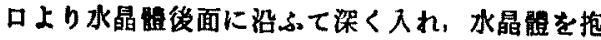

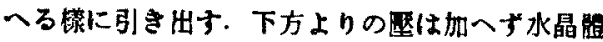

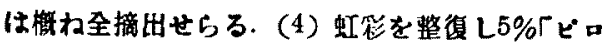
カルピン」點眼を行ひ虹波脱出を防子，綃雷其 の他の後置は一般に同じ 